Prepared in cooperation with the Department of the Navy, Naval Facilities Engineering Command, Northwest

\title{
Analysis of Groundwater Response to Tidal Fluctuations, Site 10 Naval Magazine Indian Island, Port Hadlock, Washington
}

Open-File Report 2018-1192 



\section{Analysis of Groundwater Response to Tidal Fluctuations, Site 10 Naval Magazine Indian Island, Port Hadlock, Washington}

By Chad C. Opatz and Richard S. Dinicola

Prepared in cooperation with the Department of the Navy, Naval Facilities Engineering Command, Northwest

Open-File Report 2018-1192

U.S. Department of the Interior

U.S. Geological Survey 


\section{U.S. Department of the Interior \\ RYAN K. ZINKE, Secretary}

\section{U.S. Geological Survey James F. Reilly II, Director}

U.S. Geological Survey, Reston, Virginia: 2018

For more information on the USGS—-the Federal source for science about the Earth, its natural and living resources, natural hazards, and the environment-visit https://www.usgs.gov/ or call 1-888-ASK-USGS.

For an overview of USGS information products, including maps, imagery, and publications, visit https:/store.usgs.gov.

Any use of trade, firm, or product names is for descriptive purposes only and does not imply endorsement by the U.S. Government.

Although this information product, for the most part, is in the public domain, it also may contain copyrighted materials as noted in the text. Permission to reproduce copyrighted items must be secured from the copyright owner.

Suggested citation:

Opatz, C.C., and Dinicola, R.S., 2018, Analysis of groundwater response to tidal fluctuations, Site 10 Naval Magazine Indian Island, Port Hadlock, Washington: U.S. Geological Survey Open-File Report 2018-1192, 21 p., https://doi.org/10.3133/ofr20181192.

ISSN 2331-1258 (online) 


\section{Contents}

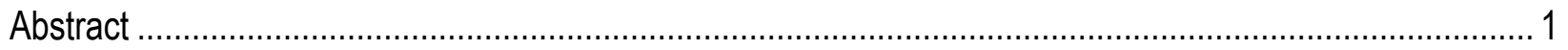

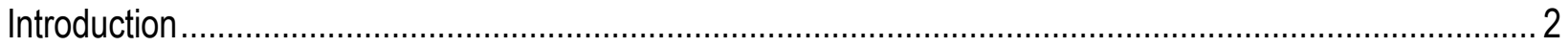

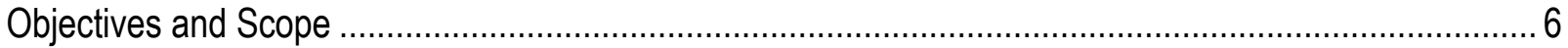

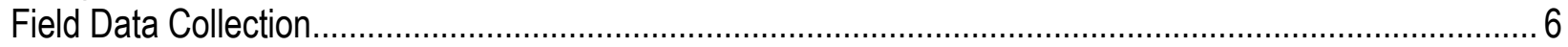

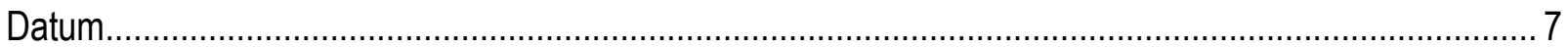

CTD Sensor Deployment and Vertical Water-Quality Profiling ........................................................ 8

CTD Sensor Retrieval and Sonde Measurements..................................................................... 10

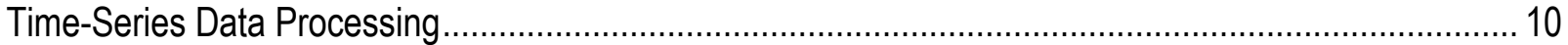

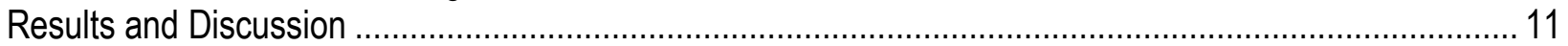

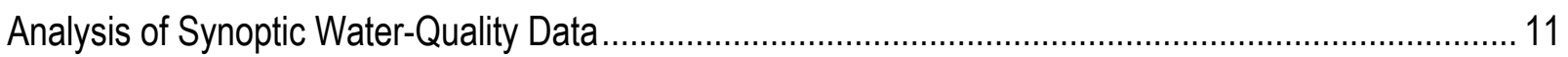

Analysis of Time Series Groundwater-Level and Specific Conductance Data....................................... 13

Tidal Lag in Monitoring Wells ............................................................................................... 17

Freshwater Occurrence and Groundwater Flow Direction at Monitoring Wells ................................. 18

Consideration of Atmospheric Conditions During Sampling........................................................... 19

Optimal Times for Groundwater Sampling ................................................................................ 20

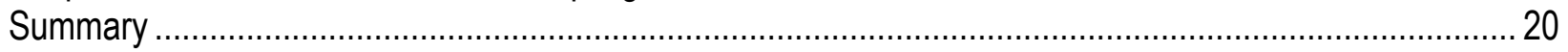

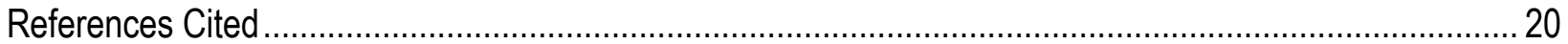

\section{Figures}

Figure 1. Location of Site 10 Northend Landfill, Naval Magazine Indian Island, Port Hadlock,

Figure 2. Locations of monitoring wells at Site 10 Northend Landfill, Naval Magazine Indian Island, Port Hadlock, Washington ................................................................................................... 5

Figure 3. Time series of groundwater level, tidal level, and specific conductance of groundwater in well MW10-6, Site 10 Naval Magazine Indian Island, Port Hadlock, Washington, April 17-May 3, 2018 .... 13 Figure 4. Time series of groundwater level, tidal level, and specific conductance of groundwater in well MW10-8, Site 10 Naval Magazine Indian Island, Port Hadlock, Washington, April 17-May 3, 2018 .... 14 Figure 5. Time series of groundwater level, tidal level, and specific conductance of groundwater in shallow well MW10-10, Site 10 Naval Magazine Indian Island, Port Hadlock, Washington, April 17-May 3, 2018.

Figure 6. Time series of groundwater level, tidal level, and specific conductance of groundwater in well MW10-11, Site 10 Naval Magazine Indian Island, Port Hadlock, Washington, April 17May 3, 2018

Figure 7. Time series of groundwater level, tidal level, and specific conductance of groundwater in well MW10-12R, Site 10 Naval Magazine Indian Island, Port Hadlock, Washington, April 17May 3, 2018

Figure 8. Water levels in monitoring wells indicating direction of hydraulic gradient at Site 10 Naval Magazine Indian Island, Port Hadlock, Washington, April 17-May 3, 2018. 


\section{Tables}

Table 1. Characteristics of monitoring wells at Site 10 Northend Landfill, Naval Magazine Indian Island, Port Hadlock, Washington ....

Table 2. Water levels measured during deployment and retrieval of the conductivity-temperature-depth sensors and a pressure logger in five Site 10 Naval Magazine Indian Island, Port Hadlock, Washington, monitoring wells and in Port Townsend Bay

Table 3. Conductivity-temperature-depth sensors and multi-parameter sonde measurements during deployment and retrieval at Site 10 Naval Magazine Indian Island, Port Hadlock, Washington ....

Table 4. Vertical water-quality profiles measured with a multi-parameter sonde at Site 10 wells prior to deployment on April 17, 2018, at Naval Magazine Indian Island, Port Hadlock, Washington....

Table 5. Lag times between the occurrence of a minimum groundwater-level elevation in a monitoring well and the preceding low tide calculated from data collected April 17-May 3, 2018, at Site 10 Naval Magazine Indian Island, Port Hadlock, Washington

\section{Conversion Factors}

U.S. customary units to International System of Units

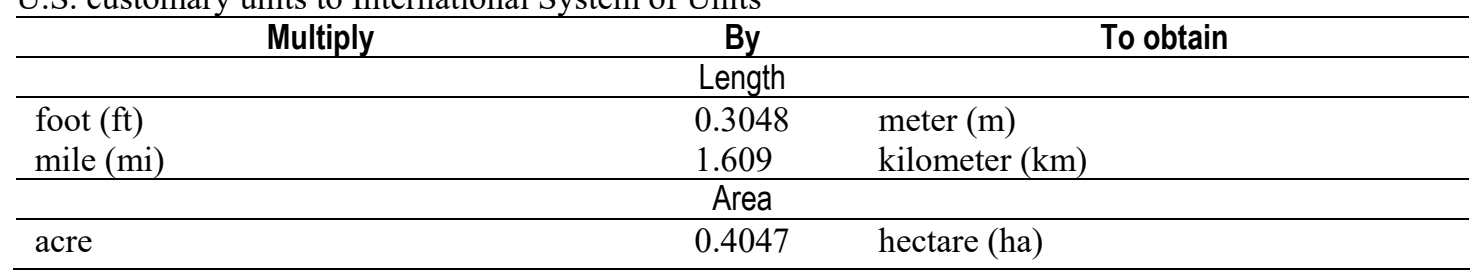

Temperature in degrees Celsius $\left({ }^{\circ} \mathrm{C}\right)$ may be converted to degrees Fahrenheit $\left({ }^{\circ} \mathrm{F}\right)$ as follows:

$$
{ }^{\circ} \mathrm{F}=\left(1.8 \times{ }^{\circ} \mathrm{C}\right)+32 \text {. }
$$

\section{Datums}

Vertical coordinate information is referenced to the Port Townsend Bay Mean Lower Low Water (MLLW) tidal level at NOAA tidal station 9444900 .

Horizontal coordinate information is referenced to the North American Datum of 1983 (NAD 83).

Elevation, as used in this report, refers to distance above the vertical datum.

\section{Supplemental Information}

Specific conductance is given in microsiemens per centimeter at 25 degrees Celsius $\left(\mu S / \mathrm{cm}\right.$ at $\left.25^{\circ} \mathrm{C}\right)$.

Concentrations of chemical constituents in water are given in either milligrams per liter $(\mathrm{mg} / \mathrm{L})$ or micrograms per liter $(\mu \mathrm{g} / \mathrm{L})$.

\section{Abbreviations}

$\begin{array}{ll}\text { MLLW } & \text { Mean Lower Low Water } \\ \text { CTD } & \text { conductivity, temperature, and depth sensor } \\ \text { TOC } & \text { top of casing } \\ \text { NAVFAC NW } & \text { Naval Facilities Engineering Command Northwest } \\ \text { NAVMAG } & \text { Naval Magazine } \\ \text { NOAA } & \text { National Oceanic and Atmospheric Administration } \\ \text { ROD } & \text { Record of Decision } \\ \text { FAMSL } & \text { feet above mean sea level } \\ \text { USGS } & \text { U.S. Geological Survey }\end{array}$




\title{
Analysis of Groundwater Response to Tidal Fluctuations, Site 10 Naval Magazine Indian Island, Port Hadlock, Washington
}

\author{
By Chad C. Opatz and Richard S. Dinicola
}

\begin{abstract}
Site 10 at Naval Magazine Indian Island is an approximately 3.7-acre inactive landfill. The site was used as the primary landfill for the island from about 1945 until the mid-1970s, receiving paints, batteries, trash, and materials. In a memorandum to Washington State Department of Ecology, Naval Facilities Engineering Command Northwest (NAVFAC NW) stipulated that a new tidal study would be conducted to recalculate tidal influence lag-time in each groundwater monitoring well at Site 10.

Groundwater levels and specific conductance in five monitoring wells, along with marine waterlevels (tidal levels) in Port Townsend Bay, were monitored every 15 minutes during a 2-week period to better understand nearshore groundwater-seawater interactions at Site 10. Time series data were collected from April 17 to May 3, 2018, a period that included neap and spring tides.

Vertical profiles of specific conductance were measured once in the screened interval of each well prior to instrument deployment to determine if a freshwater/saltwater interface was present in the well prior to instrument deployment. Profiles where measured during an ebbing tide at approximately the top, middle, and bottom of the saturated thickness within the screened interval of each well. The landward-most well, MW10-8 and coastline wells MW10-10, MW10-11 and MW10-12R, had a uniform specific conductance in the range of fresh or brackish water. Landfill monitoring well MW 10-6 showed the highest uniform specific conductance profile also in the range of brackish water.

Lag times between minimum spring-tide levels and minimum groundwater levels in wells ranged from about 0 to 4 hours. Results of lag times showed a logical increase in lag time as the distance increases from the shoreline to each monitoring well.

The specific-conductance time-series data showed minimal change in the screened interval of each well. Fluctuation of specific conductance in each well was unique but no sharp groundwater saltwater interface was observed. Increases in specific conductivity concurrent with spring low tides were measured in coastline wells, suggesting shoreward transport of high specific conductivity landfill leachate rather than seawater intrusion.

Based on all the data collected during this investigation, the optimal time for sampling monitoring wells at Site 10 would be during a $0-4$-hour period following the predicted low-low tide.
\end{abstract}




\section{Introduction}

Indian Island is an approximately 5-mile long island located in Port Hadlock, Jefferson County, Washington. Naval Magazine (NAVMAG) Indian Island occupies the island in its entirety (fig. 1). The facility primarily is used for handling and storage of naval ordnance. The Site 10 Northend Landfill is an inactive landfill approximately 3.7 acres in size. The site was used as the primary landfill for Indian Island from about 1945 until the mid-1970s. Materials reportedly disposed of in the landfill include paint, paint thinners, paint strippers, oil, lead and zinc batteries, asbestos, submarine nets, metal parts, polyurethane resins, zinc-plating slag, residential trash, ash, and drums of unidentified liquid wastes (SCS Engineers, 1987). The Record of Decision (ROD; URS, 1995) remedies were implemented in 1995, and remedial activities were completed in May 1997. Operation, maintenance, and monitoring activities were initiated in June 1997 and continue through the most current round of groundwater monitoring (round 39, June 2016). 


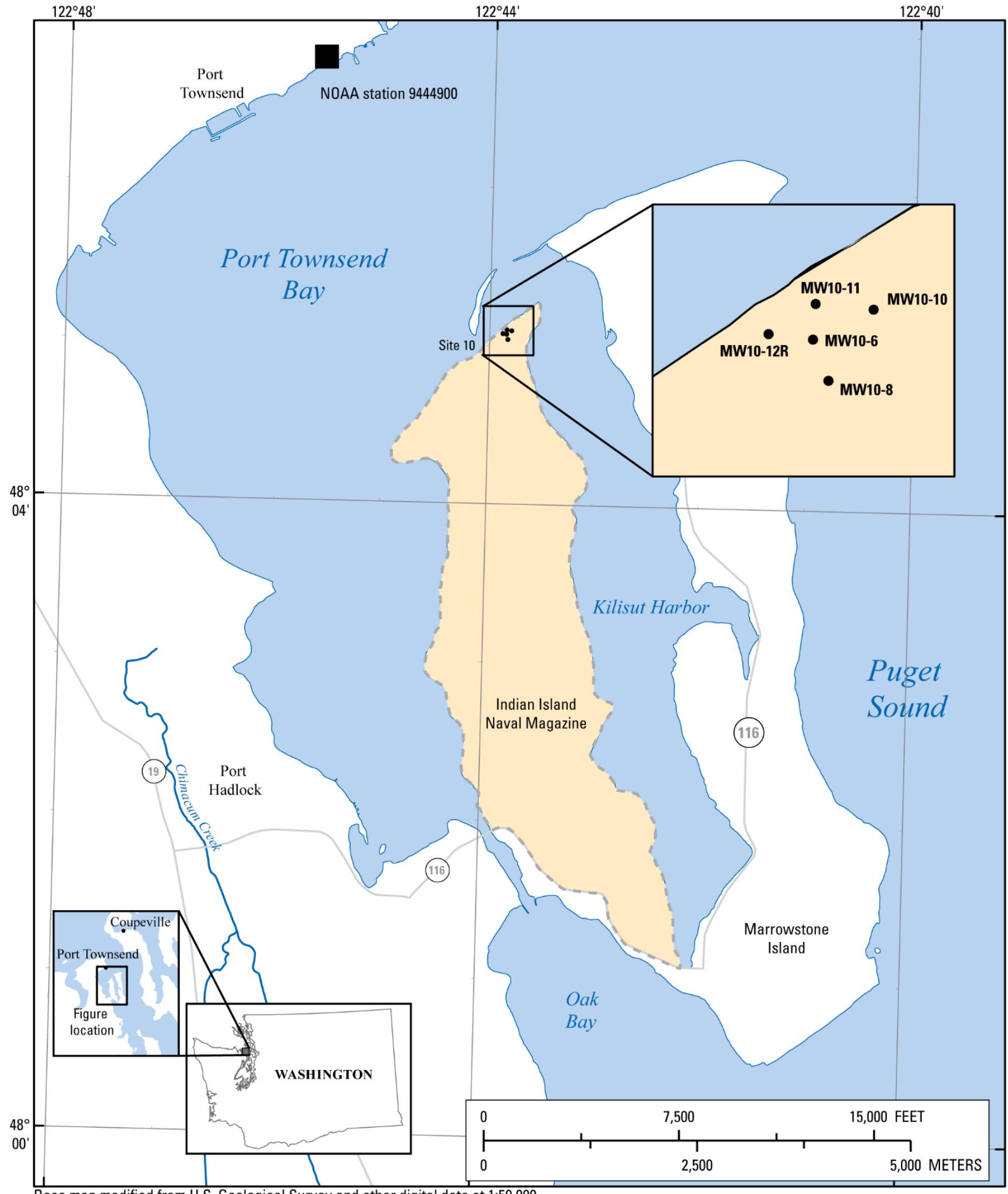

Base map modified from U.S. Geological Survey and other digital data at 1:50,000.

Coordinate Reference System State Plane Washington North.

Horizontal datum is North American Datum of 1983

Figure 1. Location of Site 10 Northend Landfill, Naval Magazine Indian Island, Port Hadlock, Washington. 
From youngest to oldest, the four principal geologic units exposed on Indian Island are recent alluvium (mixture of relatively loose gravel, sand, and silt); Vashon Till (dense sandy silt with gravel); Vashon Advance Outwash (dense sand with gravel); and Tertiary Bedrock (sandstone and shale). The thickness of debris and fill in the Site 10 Northend Landfill ranges from 4 to 10 feet (ft), and the landfill is underlain by Vashon Advance Outwash sand. Site 10 groundwater occurs at depths less than $10 \mathrm{ft}$ below land surface in the Vashon Advance Outwash and the lower part of landfill debris. Because Site 10 is located adjacent to Port Townsend Bay, groundwater flow directions change in response to semidiurnal tidal fluctuations. However, fresh groundwater flows into Site 10 from uplands to the south, so the net groundwater flow direction from Site 10 is toward Port Townsend Bay. Site 10 groundwater is too saline to be a drinking water source.

Based on discussions and agreements between Washington State Department of Ecology and Naval Facilities Engineering Command Northwest (NAVFAC NW) in May 2016, the Navy agreed to a new tidal study to determine the tidal influence lag-time in each groundwater monitoring well at Site 10 (fig. 2). To support these efforts, refined information is needed on the interaction of groundwater with seawater in response to tidal fluctuations at this nearshore site. The results of this investigation can be used to ensure that groundwater monitoring is done at an optimum time to assess contaminant concentrations in groundwater that originated at Site 10. The optimal time is presumed to be when groundwater in a well is the least mixed with seawater, conditions indicative of seaward flow of groundwater.

The shape and position of the fresh water-salt water interface in unconfined coastal aquifers varies greatly. Interface geometry is mainly influenced by local geology of the aquifer matrix, groundwater hydraulic gradient and range of tidal fluctuation. At Site 10 with a tidal sandy beach, tide and wave actions lead to the formation of an intertidal circulation cell that complements the structure of the subterranean estuary (brackish zone) between sea water and fresh water (Buquet and others, 2015). The vertical and horizontal shifting between the seawater and freshwater occur during the spring-neap tidal cycle. 


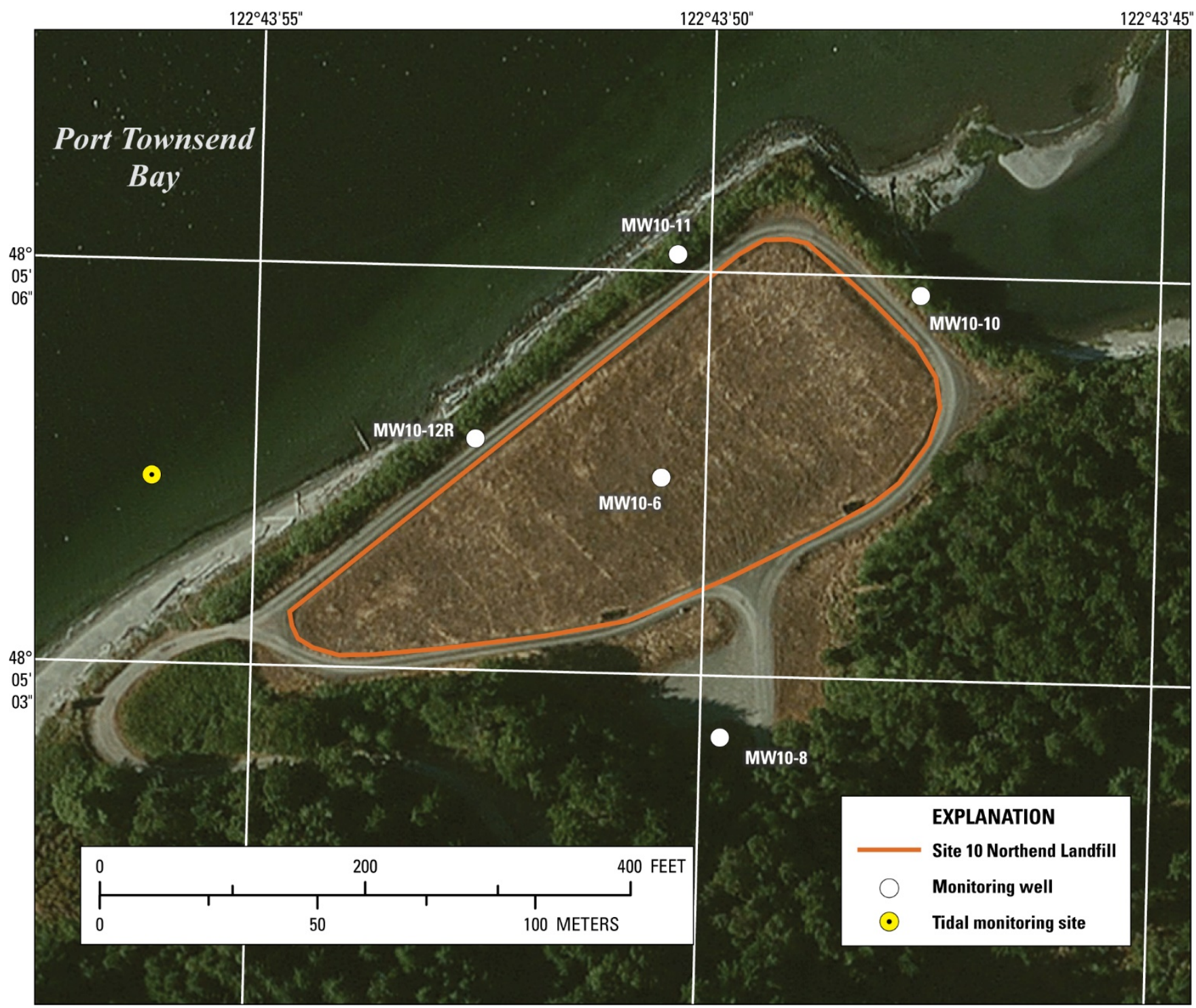

Base map modified from U.S. Geological Survey and other digital data at 1:50,000.

Coordinate Reference System State Plane Washington North.

Horizontal datum is North American Datum of 1983

Figure 2. Locations of monitoring wells and tidal monitoring site at Site 10 Northend Landfill, Naval Magazine Indian Island, Port Hadlock, Washington. 


\section{Objectives and Scope}

The overall objective of this report is to describe the data collection and analysis that has led to a better understanding of nearshore groundwater-seawater interactions at Site 10 as driven by as much as 13-ft tidal fluctuations in the adjacent Port Townsend Bay (Lincoln, 2000). The specific objective of this project was to determine the optimal time during the semi-diurnal and the neap-spring tidal cycles to sample groundwater for freshwater contaminants in Site 10 monitoring wells. To achieve that objective, tidal lag times were estimated for Site 10 nearshore monitoring wells and when during the tidal cycle the proportion of fresh groundwater relative to seawater in the wells is the largest was determined. Under the assumption when the tidal cycle reaches a lower-low level specific conductivity of the groundwater would be the lowest representing the least amount of seawater intrusion influence.

The scope of this investigation included the collection of continuous conductivity, temperature, and depth data in five groundwater monitoring wells, and in nearby Port Townsend Bay during a 2week monitoring period that included a complete spring (maximum tidal change) to neap (minimum tidal change) cycle. The scope of the data analyses included the calculation of tidal lag times, defined as the time between when a maximum or minimum tide occurred and when a subsequent maximum or minimum water level occurred in the nearshore wells, and the identification of when, during both the semi-diurnal cycle and the neap-spring tidal cycle, the measured wells have the greatest proportion of fresh groundwater.

\section{Field Data Collection}

On April 17, 2018, a U.S. Geological Survey (USGS) field team installed non-vented conductivity-temperature-depth sensors (herein referred to as CTDs) in the five Site 10 monitoring wells (table 1), and a non-vented water-level data logger in Port Townsend Bay. The CTDs were operational from April 17 to May 3, 2018. The predicted tides for that period at nearby Port Townsend, Washington (National Oceanic and Atmospheric Administration [NOAA] station 9444900) included the larger tidalrange spring tides about April 20 and May 2, 2018 and the moderate tidal-range neap tide about April 27, 2018. 
Table 1. Characteristics of monitoring wells at Site 10 Northend Landfill, Naval Magazine Indian Island, Port Hadlock, Washington.

[Well locations: Coordinate locations of Site 10 monitoring wells, referenced to the North American Datum of 1983). Measuring point elevation: Feet above mean sea level (FAMSL) as measured from top of casing. Screened interval: Top to bottom feet below top of casing of screened interval. Comments: Description of land-surface monument structure.

Abbreviation: $\mathrm{ft}$, foot]

\begin{tabular}{lcccl}
\hline $\begin{array}{c}\text { Monitoring } \\
\text { well } \\
\text { identifier }\end{array}$ & $\begin{array}{c}\text { Well locations } \\
\text { (Latitude/longitude) }\end{array}$ & $\begin{array}{c}\text { Measuring point } \\
\text { elevation } \\
\text { (FAMSL) }\end{array}$ & $\begin{array}{c}\text { Screened } \\
\text { interval } \\
\text { (ft) }\end{array}$ & Comments \\
\hline MW10-6 & $48.0847583 /-122.7294046$ & 15.83 & $4-18$ & Flush Mount \\
MW10-8 & $48.0842246 /-122.7292044$ & 22.66 & $16.5-26.5$ & Flush Mount \\
MW10-10 & $48.0851465 /-122.7286186$ & 13.4 & 4.18 & $3 \mathrm{ft}$ stick-up \\
MW10-11 & $48.0852202 /-122.7293698$ & 8.89 & $4-18$ & $1.5 \mathrm{ft}$ stick-up \\
MW10-12R & $48.0848299 /-122.7299802$ & 12.22 & $11-21$ & Flush mount \\
\hline
\end{tabular}

All sensors were calibrated and checked for accuracy in the USGS Field Services Unit prior to deployment, including three-point calibration checks on the CTDs using 250, 12,890 and 50,000 microsiemens per centimeter at $25^{\circ} \mathrm{Celsius}(\mu \mathrm{S} / \mathrm{cm})$ specific-conductance standards. The range of the calibration check was based on specific conductance that may be measured in near shore groundwater monitoring wells and is binned as (URS Consultants. Inc., 1997):

- Freshwater: specific conductance less than $1,000 \mu \mathrm{S} / \mathrm{cm}$;

- Brackish: specific conductance between 1,000 and 10,000 $\mu \mathrm{S} / \mathrm{cm}$;

- Saline/saltwater: specific conductance greater than 1,000 and $10,000 \mu \mathrm{S} / \mathrm{cm}$.

To make vertical profiles, a multi-parameter sonde equipped with $\mathrm{pH}$, dissolved oxygen, temperature, and specific conductance sensors was deployed. The multi-parameter sonde was calibrated prior to collecting measurements. The sonde was used to confirm the CTD temperature and specific conductance measurements prior to deployment. The multi-parameter sonde was used to collect synoptic vertical profile of water quality within the screened monitoring well intervals by lowering the sensor to the bottom and stopping at pre-determined intervals until parameters stabilized. Verification of water-column height above a transducer was done by collecting a depth to water less than 1 minute before the scheduled sample collection.

\section{Datum}

The datum used in this report is Port Townsend Bay Mean Lower Low Water (MLLW) tidal level at NOAA tidal station 9444900 (National Oceanic and Atmospheric Administration, 2018). In 2012, the Navy contracted a survey of the monitoring wells (top-of-casing) and two control points, CP1 and CP2, referencing mean sea level (MSL). CP2 survey information states that vertical control was derived from photogrammetric survey control referencing Port Townsend Bay MLLW tidal level at NOAA tidal station 9444900 (Sealaska Environmental, 2012). The difference between NOAA tidal station $9444900 \mathrm{MSL}$ and the MLLW datum is $5.00 \mathrm{ft}$ (https://tidesandcurrents.noaa.gov/datums.html?id=9444900); therefore, a $+5.00 \mathrm{ft}$ offset was added to discrete and continuous monitoring well water-level data to reference NOAA tidal station 9444900 MLLW datum. The elevation of the marine pressure transducer was not surveyed, but the approximate elevation (referenced to the MLLW tidal datum) was estimated by calculating the difference between daily maximum and minimum marine level monitoring data and predicted NOAA data which resulted in a mean difference of $7.77 \mathrm{ft}$. This difference was applied as the offset value to all 15-minute barometric pressure-adjusted time series marine water level monitored data to bring down to the MLLW datum. 


\section{CTD Sensor Deployment and Vertical Water-Quality Profiling}

All wells were accessed and depth-to-water measurements (table 2) were made using an electric tape. A vertical water-quality profile was collected at the top, middle, and bottom within the screened monitoring well interval. A calibrated multi-parameter sonde was inserted into each well before installation of the CTD sensor. The tide was ebbing to a low of $-0.40 \mathrm{ft}$ below MLLW during the profile measurements. The CTDs were lowered and secured at approximately mid-depth of the well screened interval for each monitoring well (table 3). Because of the relatively rapid tidally induced water-level changes in the monitoring wells, a final manual depth-to-water measurement was made immediately before the first scheduled water-level measurement recorded by the CTD in each well. Each CTD was programmed to record data at 15-minute intervals.

Table 2. Water levels measured during deployment and retrieval of the conductivity-temperature-depth sensors and a pressure logger in five Site 10 Naval Magazine Indian Island, Port Hadlock, Washington, monitoring wells and in Port Townsend Bay.

[Monitoring well identifier: Site 10 monitoring wells. Date: Date of measurement (month-day-year). Measurement time: Time (Pacific Daylight Time [[PDT]) references the nearest time-series water column height data value for an offset calculation. Water-level elevation: In feet above mean lower low water (MLLW). Depth to water from measuring point was measured immediately before or after the time each conductivity-temperature-depth sensor was programmed to sample on April 17, 2018. Barometric corrected time-series water-level data were referenced to MLLW by adding an offset derived from the equation: Offset $=(\mathrm{MP}$ elevation, in feet $[\mathrm{ft}])-($ depth-to-water $[\mathrm{ft}])-($ height of water column above transducer[ft]).

\begin{tabular}{cccc}
\hline $\begin{array}{c}\text { Monitoring } \\
\text { well } \\
\text { identifier }\end{array}$ & $\begin{array}{c}\text { Date } \\
\text { (MM-DD-YY) }\end{array}$ & $\begin{array}{c}\text { Measurement } \\
\text { time } \\
\text { (PDT) }\end{array}$ & $\begin{array}{c}\text { Water-level } \\
\text { elevation } \\
\text { (ft) }\end{array}$ \\
\hline WM10-6 & $04-17-18$ & 1211 & 5.41 \\
& $04-17-18$ & 1230 & 5.41 \\
& $05-03-18$ & 1016 & 5.87 \\
MW10-8 & $04-17-18$ & 1110 & 6.41 \\
& $04-17-18$ & 1129 & 6.38 \\
& $05-03-18$ & 1002 & 6.37 \\
MW10-10 & $04-17-18$ & 1035 & 5.67 \\
& $04-17-18$ & 1058 & 5.55 \\
& $05-03-18$ & 0946 & 6.00 \\
MW10-11 & $04-17-18$ & 0954 & 6.40 \\
& $04-17-18$ & 1029 & 5.68 \\
& $05-03-18$ & 0932 & 6.03 \\
MW10-112R & $04-17-18$ & 0842 & 6.25 \\
& $04-17-18$ & 0945 & 5.40 \\
& $05-03-18$ & 0918 & 5.94 \\
\hline
\end{tabular}


Table 3. Conductivity-temperature-depth sensors and multi-parameter sonde measurements during deployment and retrieval at Site 10 Naval Magazine Indian Island, Port Hadlock, Washington.

[Date: Date of data collection (month-day-year). Measurements time: Data were collected during Pacific Daylight Time (PDT). CTD measurements: Values measured at deployment depth. Sonde measurements: Values measured at profile depth below top of casing. Abbreviations: CTD, conductivity-temperature-depth sensor; PDT, Pacific Daylight Time; ${ }^{\circ} \mathrm{C}$, degrees Celsius; $\mu \mathrm{S} / \mathrm{cm}$, microsiemens per centimeter at 25 degrees Celsius; mg/L, milligram per liter; -, data missing]

\begin{tabular}{|c|c|c|c|c|c|c|c|c|c|c|}
\hline \multirow[b]{2}{*}{$\begin{array}{l}\text { Monitoring } \\
\text { well } \\
\text { identifier }\end{array}$} & \multirow[b]{2}{*}{$\begin{array}{l}\text { Date } \\
\text { (MM-DD- } \\
\text { YYYY) }\end{array}$} & \multirow[b]{2}{*}{$\begin{array}{c}\text { Measurement } \\
\text { time } \\
\text { (PDT) }\end{array}$} & \multicolumn{3}{|c|}{ CTD measurements } & \multicolumn{5}{|c|}{ Sonde measurements } \\
\hline & & & $\begin{array}{l}\text { Depth } \\
\text { (ft) }\end{array}$ & $\begin{array}{c}\text { Temperature } \\
\left({ }^{\circ} \mathrm{C}\right)\end{array}$ & $\begin{array}{c}\text { Specific } \\
\text { conductance } \\
(\mu \mathrm{S} / \mathrm{cm})\end{array}$ & $\begin{array}{c}\text { Depth } \\
\text { (ft) }\end{array}$ & $\begin{array}{c}\text { Temperature } \\
\left({ }^{\circ} \mathrm{C}\right)\end{array}$ & $\begin{array}{c}\text { Specific } \\
\text { conductance } \\
(\mu S / \mathrm{cm})\end{array}$ & $\mathrm{pH}$ & $\begin{array}{c}\text { Dissolved } \\
\text { oxygen } \\
\text { (mg/L) }\end{array}$ \\
\hline \multirow[t]{3}{*}{ MW10-6 } & $04-17-2018$ & 1215 & 16 & - & - & 18 & 11.38 & 5,341 & 6.72 & 0 \\
\hline & $04-18 / 2018$ & 0215 & 16 & 11.20 & 3,415 & - & - & - & - & - \\
\hline & $05-03-2018$ & 1015 & 16 & 11.32 & 5,956 & 16 & - & - & - & - \\
\hline \multirow[t]{2}{*}{ MW10-8 } & 04-17-2018 & 1014 & 25 & 11.06 & 351 & 22 & 10.55 & 504 & 6.67 & 9.80 \\
\hline & 05-03-2018 & 1002 & 25 & 10.62 & 540 & 25 & 10.83 & 540 & 6.62 & 10.26 \\
\hline \multirow[t]{2}{*}{ MW10-10 } & 04-17-2018 & 1041 & 17 & 10.96 & 447 & 17 & 10.67 & 828 & 6.58 & 0 \\
\hline & $05-03-2018$ & 0946 & 17 & 10.56 & 475 & 17 & 10.46 & 364 & 6.65 & 4.80 \\
\hline \multirow[t]{2}{*}{ MW10-11 } & $04-17-2018$ & 1009 & 16 & 12.05 & 241 & 16 & 10.66 & 406 & 6.86 & 0.63 \\
\hline & 05-03-2018 & 0932 & 16 & 10.19 & 491 & 16 & 10.19 & 491 & 7.01 & 7.73 \\
\hline \multirow[t]{2}{*}{ MW10-12R } & 04-17-2018 & 0935 & 19 & 11.06 & 2,095 & 20 & 10.95 & 2,055 & 6.42 & 0 \\
\hline & 05-03-2018 & 0918 & 19 & 10.99 & 2,034 & 19 & 10.95 & 2,003 & 6.45 & 14.13 \\
\hline
\end{tabular}


A water-level data logger was deployed offshore in the marine water approximately $250 \mathrm{ft}$ west of MW10-12R to measure tidal levels. The transducer was anchored in place at a fixed location on the marine floor, with a buoy attached to the anchor to facilitate retrieval. The transducer was deployed at a time (1154 Pacific Daylight Time [PDT]) and location when the marine water depth was $5.5 \mathrm{ft}$, a depth that ensured the transducer would remain submerged at the predicted lowest tide during the deployment. The predicted tide at that time for the nearest reporting site at Port Townsend, Washington (NOAA Station 9444900) was about $-0.4 \mathrm{ft}$ below MLLW.

Because the transducer and CTDs were non-vented, a barometric pressure data logger was installed onshore in the immediate area to collect atmospheric pressure data used to correct non-vented marine and groundwater-level data.

\section{CTD Sensor Retrieval and Sonde Measurements}

On May 3, 2018, a USGS field team retrieved CTDs from five monitoring wells and a waterlevel data logger in Port Townsend Bay. All wells were accessed and depth-to-water measurements were recorded prior to the final 15-minute CTD measurement (table 1). Immediately after CTD retrieval, the multi-parameter sonde was lowered to the CTD measurement elevation in each well to measure water quality. The CTD retrieval likely agitated the water column in the well, so an exact match between CTD and sonde measurements was not expected. It was clear after review of the sonde and CTD comparison of specific conductance values that the sonde specific conductance probe was not fully submerged in well water after the MW10-6 CTD was retrieved (table 3).

\section{Time-Series Data Processing}

The 15-minute time-series data from the CTDs were downloaded in the field. Groundwater and marine time-series water-level data were measured with non-vented pressure transducers and adjusted for changes in atmospheric pressure by subtracting the measured atmospheric (barometric) pressure from pressure transducer measurements for each 15-minute value, with due consideration of units. 


\section{Results and Discussion}

\section{Analysis of Synoptic Water-Quality Data}

Water-quality measurements made by the CTDs and the multi-parameter sonde during deployment and retrieval of the CTDs did not compare in some wells (table 3). Variation between the two data sets was expected due to slightly different measurement elevations on April 17 when the sonde could be lowered only to just above the CTD, and due to agitated well water when the sonde measurements followed CTD retrieval on May 3. Upon deployment at wells MW10-8, MW10-10, and MW10-11 the CTD/sonde comparison showed a greater than 30 percent difference, whereas when retrieved $\mathrm{CTD} /$ sonde comparison difference at MW10-10 remained at 25 percent. A three-point calibration check $(100,1,000$ and $12,890 \mu \mathrm{S})$ was done for each CTD and the multi-parameter sonde 1 day before deployment, which showed that all instrumentation was calibrated with in less than or equal to 3 percent. This calibration data indicated that the sonde data was considered good-quality data, whereas CTD specific conductance values were poor. The poor comparison between the sonde and CTD data during field measurements and the unexpected drift and steps in specific conductance data trends (figs .3-5) provides evidence of poor CTD quality data, particularly in MW10-11 (fig. 6).

The CTD conductivity probe in well MW10-6 did not equilibrate to groundwater conditions once positioned at deployment depth for multi parameter sonde comparison. Air bubbles in the CTD conductivity sampling port were likely the cause. It seems that the bubbles eventually dissolved in solution after approximately 16 hours at 0215 on April 18, 2018. At that time the CTD started logging temperature and specific conductance data but the comparison to the sonde data collected April 17, 2018 was poor.

The vertical water-quality profile data indicated little variation across the saturated screened interval prior to CTD sensor deployment (table 4). The tide was ebbing to a low of $-0.4 \mathrm{ft}$ at 1145 PDT followed by flooding up to $0.38 \mathrm{ft}$ (above MLLW) when the profiles were measured. During this spring tide period, groundwater in the most landward well MW10-8 was fresh across the entire screened interval with specific conductance ranging from 484 to $504 \mu \mathrm{S} / \mathrm{cm}$. Groundwater in the coastline wells also had uniform profiles within each screened interval ranging in either brackish or fresh water. Specific conductance in MW10-12R ranged from 2,043 to 2,055 $\mu \mathrm{S} / \mathrm{cm}$, whereas groundwater across the entire screened interval of both MW10-11 and MW10-10 ranged in specific conductance from 406 to $828 \mu \mathrm{S} / \mathrm{cm}$. The vertical groundwater profile of MW10-6 located in the landfill was uniformly brackish ranging from 5,295 to $5,341 \mu \mathrm{S} / \mathrm{cm}$. The conversion from specific conductance to salinity cannot be made precisely without additional data, but ambient Puget Sound water with specific conductance of about $45,000 \mu \mathrm{S} / \mathrm{cm}$ would have a salinity of about 29 parts per thousand, and brackish water with a specific conductance of about $5,000 \mu \mathrm{S} / \mathrm{cm}$ would have a salinity of about 3 parts per thousand (Moore and others, 2017).

Overall, the vertical profile data indicate a uniform specific conductivity within the screened interval of each monitoring well, so no freshwater/saltwater interfaces were present in any of the well screens. Thus, when sampling for contaminants in the wells, a mid-screen sampling location is considered the best location. 
Table 4. Vertical water-quality profiles measured with a multi-parameter sonde at Site 10 wells prior to deployment on April 17, 2018, at Naval Magazine Indian Island, Port Hadlock, Washington.

[Measurement depth: Depth below top of casing where measurement was collected. Tidal level: Estimate of tidal level above mean lower low water. MLLW-Est, Mean Lower Low Water estimated from NOAA tidal level curve between daily highs and lows. Abbreviations: ${ }^{\circ} \mathrm{C}$, degrees Celsius; $\mathrm{ft}$, foot; $\mathrm{mg} / \mathrm{L}$, milligram per liter; $\mu \mathrm{S} / \mathrm{cm}$, microsiemens per centimeter at $25^{\circ} \mathrm{C}$; NOAA, National Oceanic and Atmospheric Administration]

\begin{tabular}{|c|c|c|c|c|c|c|c|}
\hline $\begin{array}{l}\text { Monitoring } \\
\text { well } \\
\text { identifier }\end{array}$ & Time & $\begin{array}{l}\text { Measurement depth } \\
\text { ( } \mathrm{ft} \text { below } \\
\text { top of casing) }\end{array}$ & $\mathrm{pH}$ & $\begin{array}{l}\text { Dissolved oxygen } \\
\text { (mg/L) }\end{array}$ & $\begin{array}{l}\text { Temperature } \\
\left({ }^{\circ} \mathrm{C}\right)\end{array}$ & $\begin{array}{c}\text { Specific } \\
\text { conductance } \\
(\mu \mathrm{S} / \mathrm{cm})\end{array}$ & $\begin{array}{c}\text { Tidal level } \\
\text { (ft above MLLW-Est) }\end{array}$ \\
\hline \multirow[t]{2}{*}{ MW10-6 } & 1215 & 16 & 6.71 & 0 & 11.2 & 5,295 & -0.20 \\
\hline & 1219 & 18 & 6.72 & 0 & 11.38 & 5,341 & -0.19 \\
\hline \multirow[t]{2}{*}{ MW10-8 } & 1114 & 22 & 6.67 & 10.66 & 10.57 & 484 & 0.00 \\
\hline & 1120 & 26.5 & 6.55 & 9.80 & 10.55 & 504 & -0.05 \\
\hline \multirow[t]{2}{*}{ MW10-10 } & 1041 & 13 & 6.83 & 5.33 & 10.42 & 770 & 0.40 \\
\hline & 1045 & 17 & 6.58 & 0 & 9.36 & 828 & 0.35 \\
\hline \multirow[t]{3}{*}{ MW10-11 } & 1009 & 7.5 & 7.52 & 2.02 & 9.36 & 422 & 1.20 \\
\hline & 1012 & 11.5 & 7.05 & 0.46 & 9.44 & 408 & 1.15 \\
\hline & 1015 & 16 & 6.86 & 0.63 & 9.81 & 406 & 1.14 \\
\hline \multirow[t]{3}{*}{ MW10-12R } & 0912 & 12 & 6.28 & 4.78 & 10.38 & 2,043 & 3.10 \\
\hline & 0920 & 16 & 6.38 & 0 & 10.66 & 2,054 & 3.00 \\
\hline & 0935 & 20 & 6.42 & 0 & 10.95 & 2,055 & 2.90 \\
\hline
\end{tabular}




\section{Analysis of Time Series Groundwater-Level and Specific Conductance Data}

Time-series plots of groundwater levels, tidal level, head difference, and specific conductance are shown in figures 3-7 for the five Site 10 wells. Groundwater levels and tidal levels are referenced to feet above MLLW on the primary y-axis with a fixed range in all five figures. The head difference line is the difference between tidal level and groundwater level at each time step representing the hydraulic gradient relative to zero where positive is coastline groundwater flow direction and negative is landward groundwater flow direction. Specific conductance is referenced to the secondary y-axis with different yaxis ranges for each figure.

Groundwater levels fluctuated semi-diurnally in concert with, but attenuated in time and magnitude with, the semi-diurnal tides. The lowest groundwater levels measured in all shallow wells were associated with the spring tides around April 21 when the tidal levels were lowest.

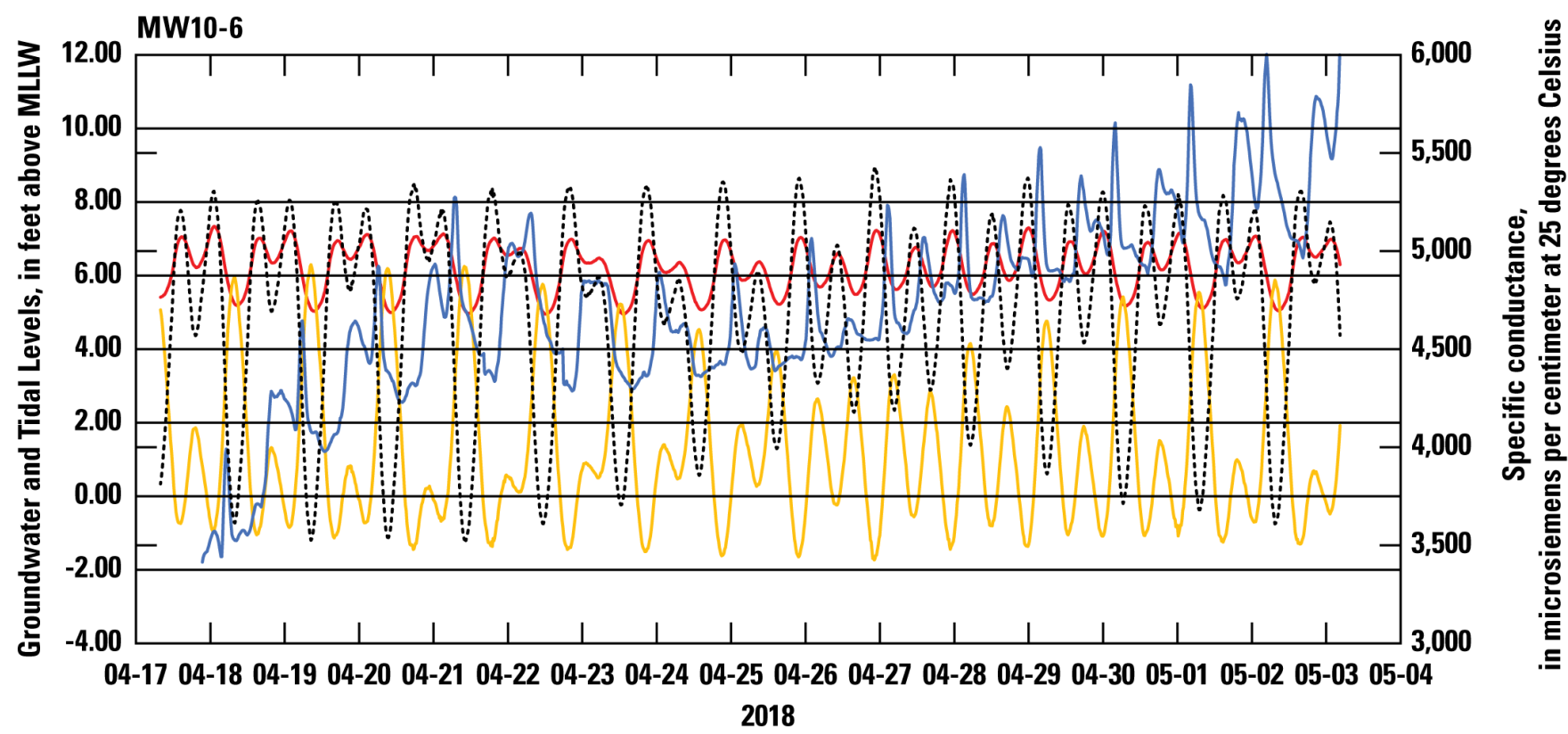

EXPLANATION

$\begin{array}{ll}\text { - } & \text { Groundwater level } \\ \text { - Head difference } \\ \ldots . . . & \text { Tide level } \\ - & \text { Specific conductance }\end{array}$

Figure 3. Time series of groundwater level, tidal level, and specific conductance of groundwater in well MW10-6, Site 10 Naval Magazine Indian Island, Port Hadlock, Washington, April 17-May 3, 2018. Groundwater and tidal levels are referenced to feet above mean lower low water (MLLW) on the primary y-axis with a fixed range $(-2.00$ to 12.00 feet above MLLW). The head difference is the difference between tidal level and groundwater level at each time step representing the hydraulic gradient relative to zero where positive is coastline groundwater flow and negative is landward groundwater flow direction. 


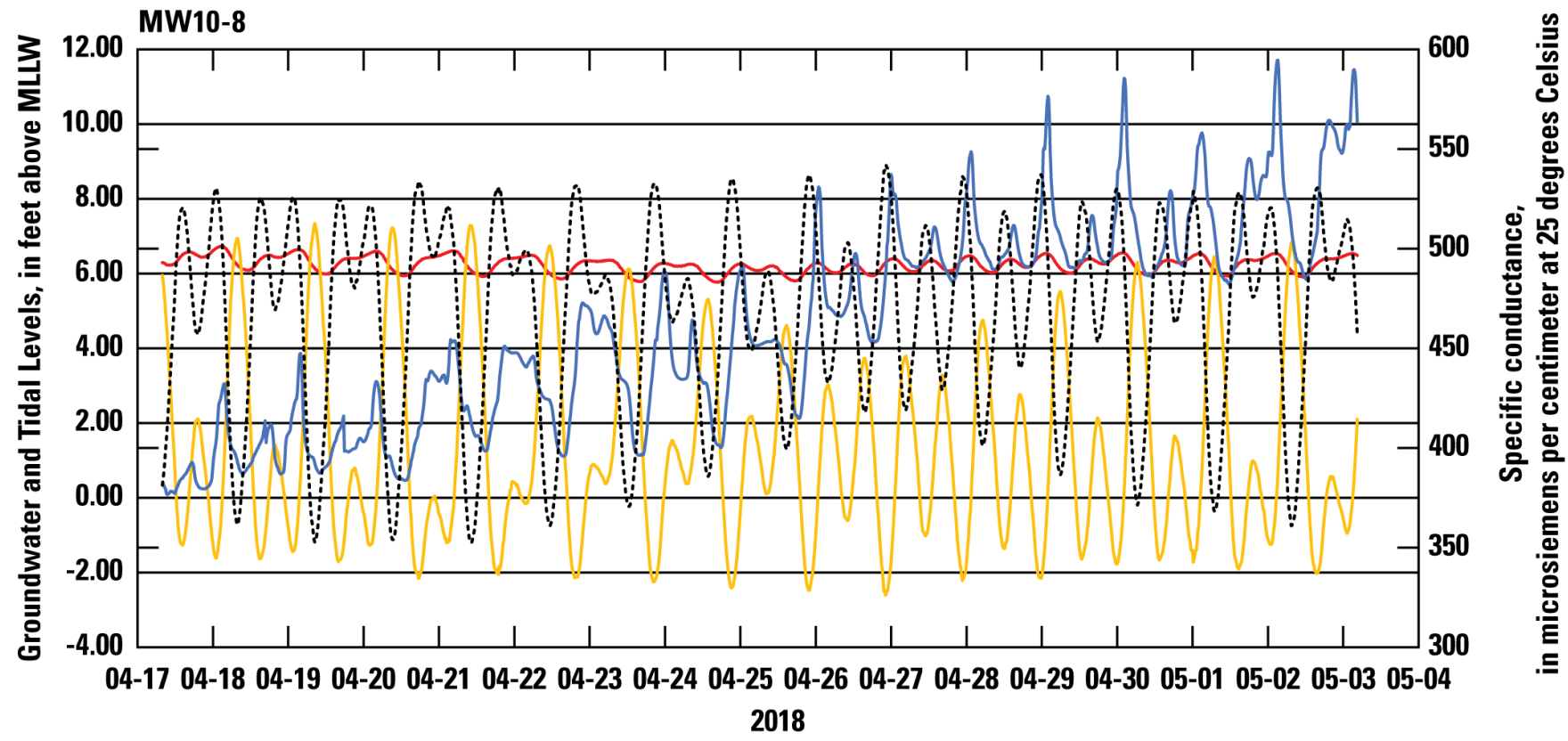

\section{EXPLANATION}

- Groundwater level

- Head difference

...... Tide level

- Specific conductance

Figure 4. Time series of groundwater level, tidal level, and specific conductance of groundwater in well MW10-8, Site 10 Naval Magazine Indian Island, Port Hadlock, Washington, April 17-May 3, 2018. Groundwater and tidal levels are referenced to feet above mean lower low water (MLLW) on the primary y-axis with a fixed range (-2.00 to 12.00 feet above MLLW). The head difference is the difference between tidal level and groundwater level at each time step representing the hydraulic gradient relative to zero where positive is coastline groundwater flow and negative is landward groundwater flow direction. 


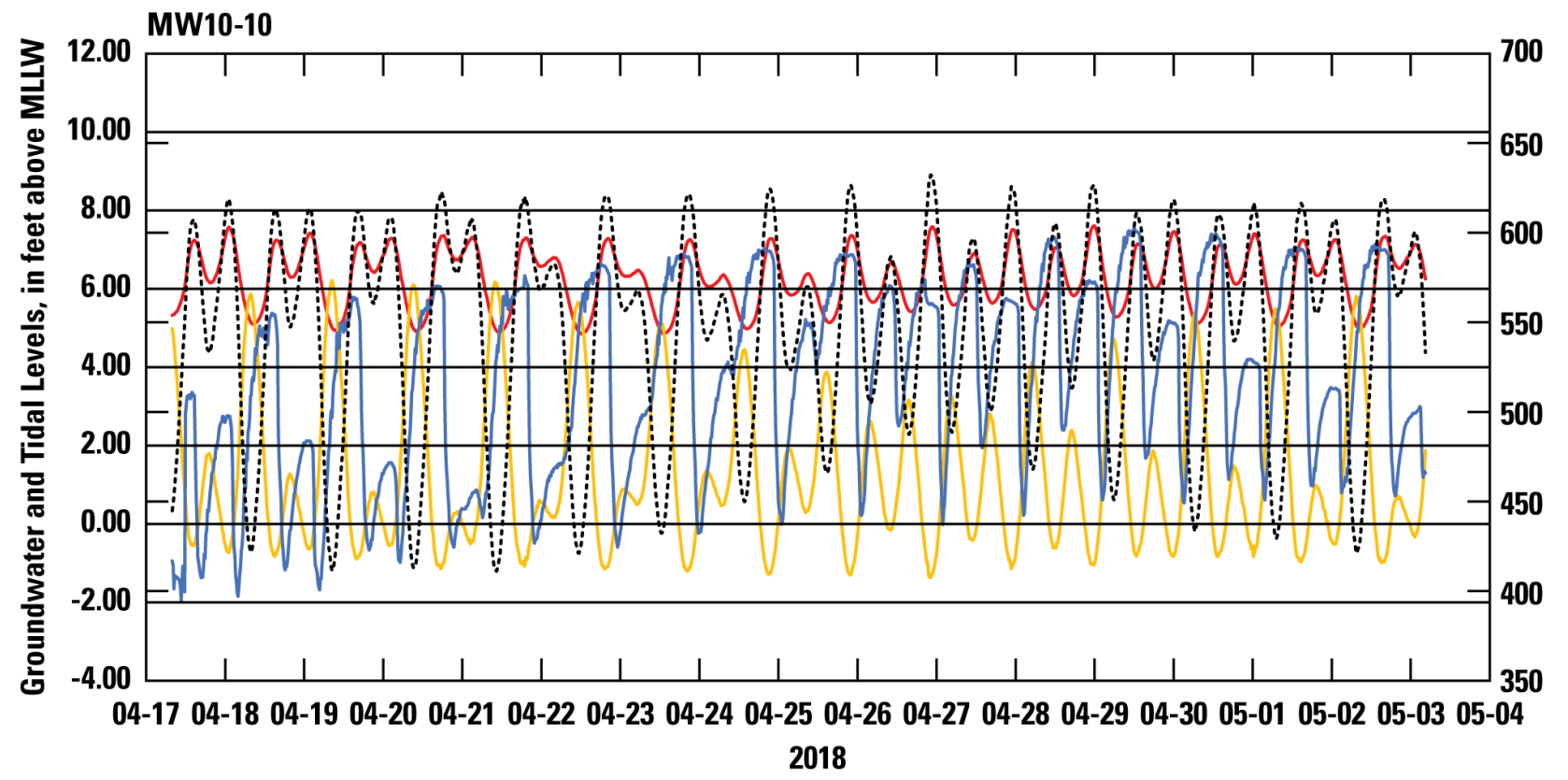

\section{EXPLANATION}

- Groundwater level

- Head difference

....... Tide level

- Specific conductance

Figure 5. Time series of groundwater level, tidal level, and specific conductance of groundwater in shallow well MW10-10, Site 10 Naval Magazine Indian Island, Port Hadlock, Washington, April 17-May 3, 2018. Groundwater and tidal level are referenced to feet above MLLW on the primary y-axis with a fixed range $(-2.00$ to12.00 feet above MLLW). The head difference line is the difference between tidal level and groundwater level at each time step representing the hydraulic gradient relative to zero where positive is coastline groundwater flow and negative is landward groundwater flow direction. 


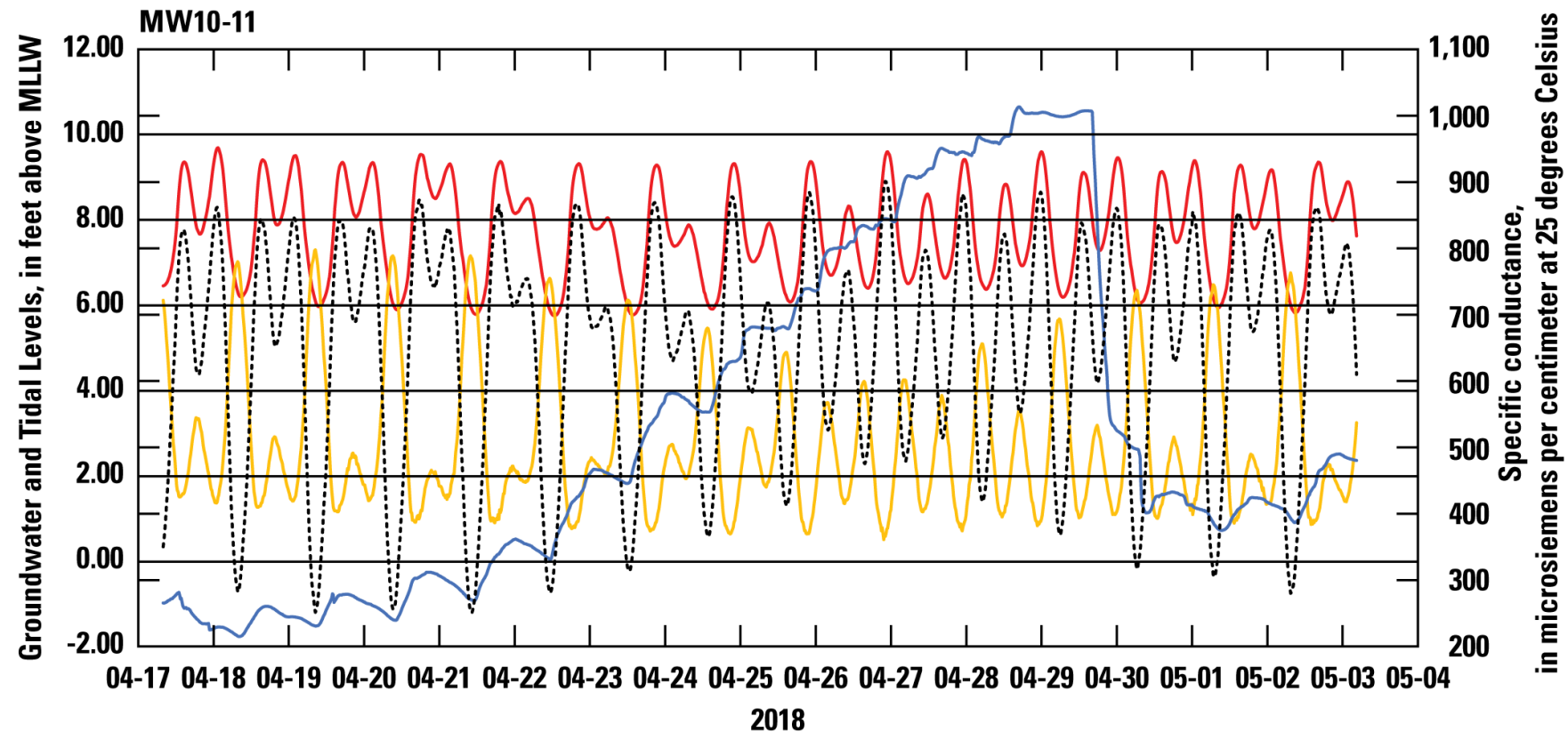

\section{EXPLANATION}

_ Groundwater level

- Head difference

...... Tide level

- Specific conductance

Figure 6. Time series of groundwater level, tidal level, and specific conductance of groundwater in well MW10-11, Site 10 Naval Magazine Indian Island, Port Hadlock, Washington, April 17-May 3, 2018. Groundwater and tidal level are referenced to feet above MLLW on the primary y-axis with a fixed range (-2.00 to12.00 feet above MLLW). The head difference line is the difference between tidal level and groundwater level at each time step representing the hydraulic gradient relative to zero where positive is coastline groundwater flow and negative is landward groundwater flow direction. 


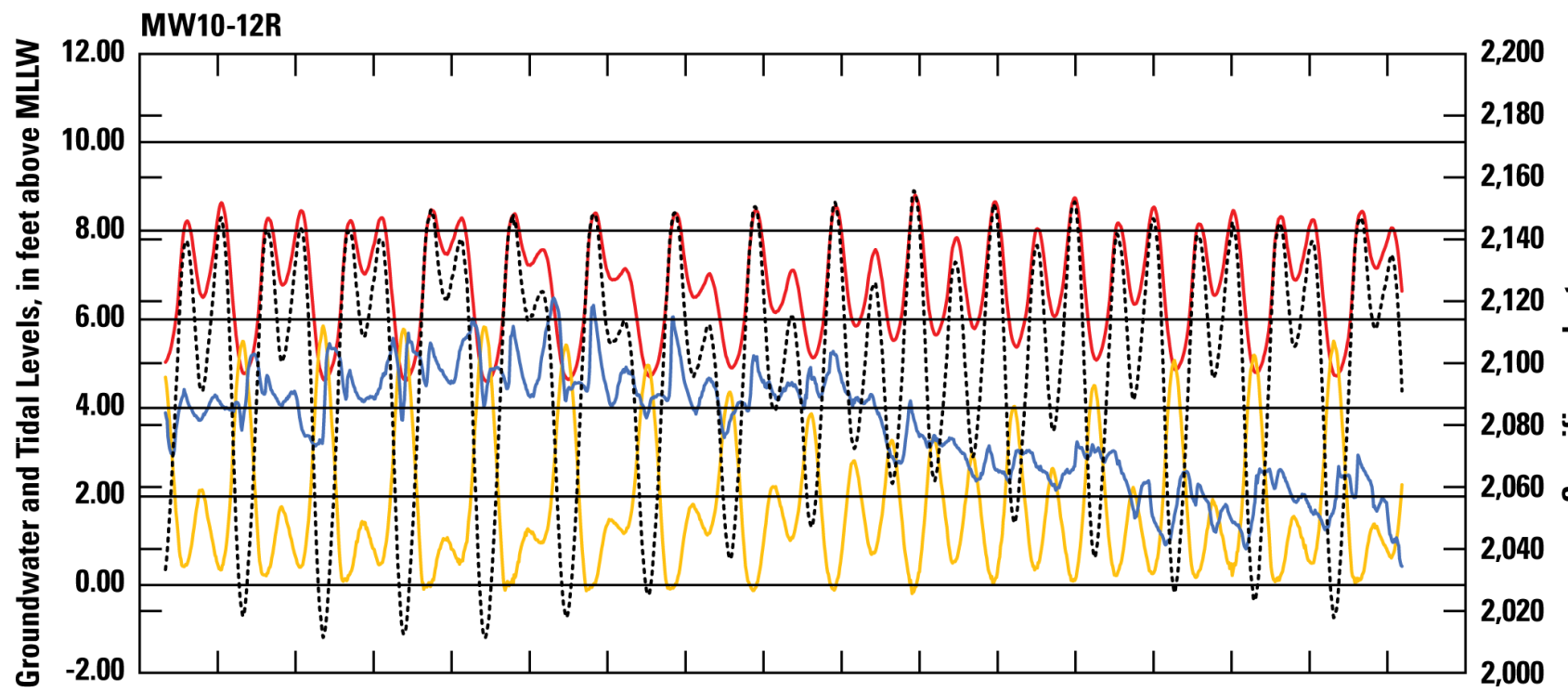

04-17 04-18 04-19 04-20 04-21 04-22 04-23 04-24 04-25 04-26 04-27 04-28 04-29 04-30 05-01 05-02 05-03 05-04 2018

EXPLANATION

$\begin{array}{ll}- & \text { Groundwater level } \\ - & \text { Head difference } \\ \ldots . . . & \text { Tide level } \\ - & \text { Specific conductance }\end{array}$

Figure 7. Time series of groundwater level, tidal level, and specific conductance of groundwater in well MW1012R, Site 10 Naval Magazine Indian Island, Port Hadlock, Washington, April 17-May 3, 2018. Groundwater and tidal level are referenced to feet above MLLW on the primary y-axis with a fixed range $(-2.00$ to12.00 feet above MLLW). The head difference line is the difference between tidal level and groundwater level at each time step representing the hydraulic gradient relative to zero where positive is coastline groundwater flow and negative is landward groundwater flow direction.

\section{Tidal Lag in Monitoring Wells}

The groundwater level time series data from each well, and the corresponding tidal level data (figs. 3-7), were used to estimate tidal lag times (table 5). Groundwater levels in monitoring wells, as well as tidal levels, exhibited two diurnal highs and lows throughout the entire spring to neap to spring period monitored. Each semi-diurnal low-low tidal level was followed by a low-low groundwater level in the wells. The time durations between the tidal and groundwater low-lows were calculated as the tidal lag times for each well. Over the duration of the entire time series, tidal lag times ranged from 0 to 4 hours. The longest tidal lags (2.25-4 hours) were measured in the most landward well, MW10-8, whereas tidal lags between $0-1.5$ hours were measured in all other Site 10 wells 
Table 5. Lag times between the occurrence of a minimum groundwater-level elevation in a monitoring well and the preceding low tide calculated from data collected April 17-May 3, 2018, at Site 10 Naval Magazine Indian Island, Port Hadlock, Washington.

\begin{tabular}{cc}
\hline $\begin{array}{c}\text { Monitoring } \\
\text { well } \\
\text { identifier }\end{array}$ & $\begin{array}{c}\text { Lag times between recorded minimum } \\
\text { tide and minimum groundwater levels } \\
\text { (hours) }\end{array}$ \\
\hline MW10-6 & $0.5-1.25$ \\
MW10-8 & $2.25-4$ \\
MW10-10 & $0.25-1$ \\
MW10-11 & $1-1.50$ \\
MW10-12R & $0-0.75$ \\
\hline
\end{tabular}

\section{Freshwater Occurrence and Groundwater Flow Direction at Monitoring Wells}

Specific conductance in all wells responded to tidal fluctuations by increasing or decreasing, although the data indicate that specific conductance may be elevated in Site 10 wells due to landfill leachate more than seawater intrusion. Through semi-diurnal tidal cycles and across neap and spring tidal periods, specific conductance in all wells remained within either fresh or brackish water.

Groundwater with the highest specific conductance was consistently measured at MW10-6, in the interior of the landfill. That brackish water most likely is due to landfill leachate rather that marine water intrusion because the wells seaward of MW10-6 all had consistently lower specific conductance, and specific conductance would generally increase when water-level (head) differences between groundwater and marine water became less than 0, indicating landward flow (fig. 3). As expected, groundwater within the well upgradient of the landfill (MW10-8) was consistently fresh, and specific conductance slightly increased when head differences indicated landward flow (fig. 4), likely due to mixing with some landfill leachate. Groundwater in two of the shoreline wells (MW10-10 and MW10-11) also was consistently fresh, whereas groundwater in the shoreline well MW10-12R was consistently brackish. Unexpectedly, there was essentially no reversal of the hydraulic gradient to landward at wells MW10-11 and MW1-12R, although there was a daily or twice daily reversal at well MW10-10 (figs. 5 and 8) during the monitored period. Among these three shoreline wells, there was no consistent pattern of when and in what direction specific conductance changed in concert with tides, suggesting that the tidally induced movement of landfill leachate with variable specific conductance, rather than seawater, was responsible for the diurnal changes in specific conductance. 


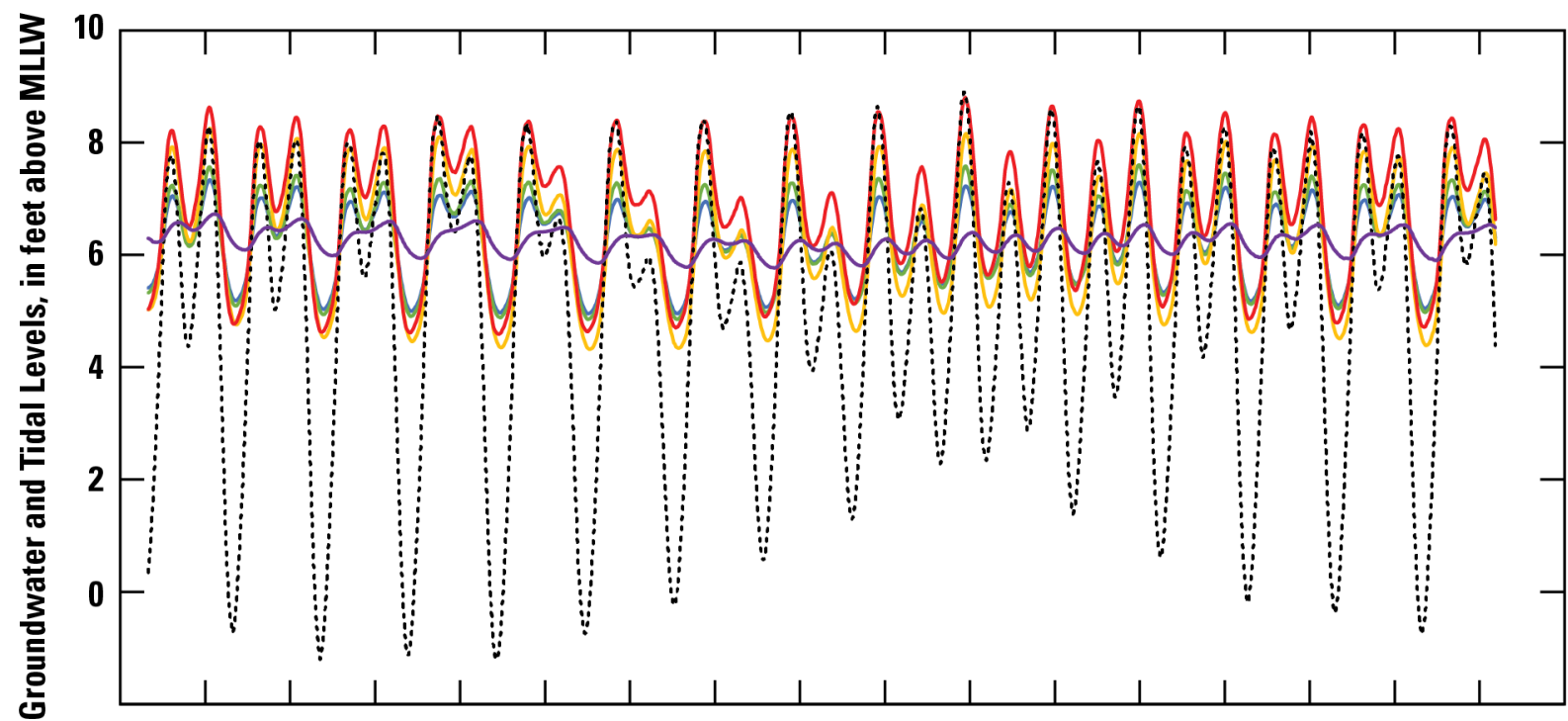

04-17 04-18 04-19 04-20 04-21 04-22 04-23 04-24 04-25 04-26 04-27 04-28 04-29 04-30 05-01 05-02 05-03 05-04 2018

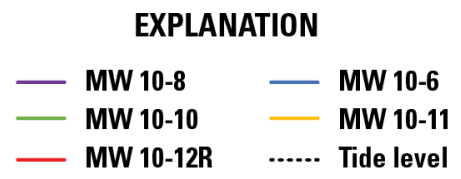

Figure 8. Water levels in monitoring wells indicating direction of hydraulic gradient at Site 10 Naval Magazine Indian Island, Port Hadlock, Washington, April 17-May 3, 2018.

Overall, seawater intrusion appears to be minimal at Site 10 monitoring wells, so changes in specific conductance should not be a major consideration of when to best sample undiluted groundwater. Seawater intrusion most likely is limited by the steep groundwater gradient seaward driven by immediate topographic relief south of Site 10 .

The freshwater-saltwater interface geometry at Site 10 is greatly influenced by the local steep groundwater gradient inducing a high degree of horizontal force on the interface creating a steep geometry. A sharp specific conductivity interface from freshwater or brackish to saltwater was not measured during screen interval profiling nor captured over the spring-neap tidal cycle by time-series data providing evidence that the interface remains a distance both horizontally and vertically away from the monitored depth of all wells at Site 10.

\section{Consideration of Atmospheric Conditions During Sampling}

Atmospheric conditions can greatly influence predicted tidal fluctuations (Opatz and Dinicola, 2018). Atmospheric conditions remained stable during monitoring at Site 10 (Opatz, 2018). Attention to local forecast prior to sampling will ensure optimal sampling conditions described in this report for Site 10 Naval Magazine Indian Island, Port Hadlock, Washington. Forecast conditions to consider avoiding would be high winds from the north and exceptionally low barometric pressure associated with a storm front (Opatz and Dinicola, 2018). Those conditions have the potential to create less coastward groundwater flow caused by higher low-low tidal levels than predicted during groundwater sampling. 


\section{Optimal Times for Groundwater Sampling}

With all data considered, the optimal steps for sampling the coastline monitoring wells and landfill monitoring well MW10-6 at Site 10, along with other sampling period considerations would be to in following summary list:

- Check the local forecast for stable atmospheric pressure and wind conditions on the scheduled day of sampling.

- Sample coastline well MW10-12R centered on a 0-0.75-hour period after the predicted spring lower-low tide.

- Sample coastline well MW10-10 centered on a 0.25-1-hour period after the predicted spring lower-low tide.

- Sample coastline well MW10-11 centered on a 1-1.5-hour period after the predicted spring lowlower tide.

- Sample background well MW10-8 three hours following the predicted spring low-low tide

- Position sampling point at mid screen of each monitoring well.

The specific time period listed to sample each well are periods when groundwater in the wells is most representative of coastward groundwater flow.

\section{Summary}

Groundwater and tidal levels were monitored at Site 10 inactive landfill on Naval Magazine Indian Island for estimating lag times between minimum spring-tide levels and minimum groundwater levels in wells for determining when groundwater sampling would be least impacted my saltwater intrusion. Both discrete and continuous water data were collected in five monitoring wells and in Port Townsend Bay. Water quality profiles across the monitoring well screened interval were measured and 15-minute time-series data of specific conductivity, temperature and water depth were recorded for a 2week period.

Estimated lag times were found increasing with distance from coastline landward in all monitoring wells ranging from 0-4 hours. A freshwater/saltwater interface was not recorded in any coastline wells nor was specific conductivity values in the range of saltwater recorded. In fact, coastline wells remained either fresh or brackish with little variation over the monitored period suggesting minimal seawater intrusion at Site 10. The highest specific conductivity recorded was in the landfill monitoring well (MW10-6) most likely is due to landfill leachate rather that saltwater intrusion given the landfill is located up-gradient from coastline wells.

\section{References Cited}

Buquet, D., 2015, Shape of the shallow aquifer at the fresh water-sea water interface on a high-energy sandy beach: Estuarine Coastal and Shelf Science, v. 179, p. 79-89.

Lincoln, J.H., 2000, The Puget Sound Model Summary: University of Washington, Department of Oceanography, accessed September 12, 2018, https://web.archive.org/web/20150310034800/http://exhibits.pacsci.org/Puget_Sound/PSSummary.ht $\mathrm{ml}$. 
Moore, S., Wold, R., Stark, K., Bos, J., Williams, P., Hamel, N., Edwards, A., Krembs, C., and Newton, J., 2017, Puget Sound marine waters-2016 overview: Prepared by National Oceanic and Atmospheric Administration Northwest Fisheries Science Center for the Puget Sound Ecosystem Monitoring Program Marine Waters Workgroup, 56 p., accessed September 12, 2018, www.psp.wa.gov/PSmarinewatersoverview.php.

National Oceanic and Atmospheric Administration, 2018, Tides and currents_-Datums for 9444900, Port Townsend, Washington: National Oceanic and Atmospheric Administration, web site, accessed May 15, 2018, at https://tidesandcurrents.noaa.gov/datums.html?id=9444900.

Opatz, C.C., 2018, Groundwater and Tidal Time Series Data, Naval Magazine Indian Island, Port Hadlock, WA: U.S. Geological Survey, https://doi.org/10.5066/F7JW8D5S.

Opatz, C.C., Dinicola, R.S., 2018, Analysis of Groundwater Response to Tidal Fluctuations, Operable Unit 2, Area 8, Naval Base Kitsap, Keyport, Washington: U.S. Geological Survey Open-File Report 2018-1082, 20 p., https://doi.org/10.3133/ofr20181082.

Sealaska Environmental, 2012, Final Technical Memorandum, Groundwater Monitoring Well MW1012R Installation, Task Order 62, Site 10 Northend Landfill, Naval Magazine Indian Island, Port Hadlock, Washington: Professional Survey of Naval Magazine Island -Site 10, Prepared by: Ruef, W.A., 2012, Coordinate and Elevation Table, p. 19.

SCS Engineers, 1987, Current Situation Report (CSR), Naval Undersea Warfare Engineering Station, Keyport and Indian Island, Washington: SCS Engineers report.

URS Consultants, Inc., 1995, Final record of decision-Comprehensive long-term environmental action Navy (clean) northwest area-Port Hadlock Detachment (U.S. Navy) Sites 10, 11, 12, 15, 18, 19, 20 , 21, and 22: Prepared by URS Consultants Inc., Seattle, Washington, for Engineering Field Activity, Northwest, Naval Facilities Engineering Command, EPA/ROD/R10-95/129, 54 p.

URS Consultants, Inc., 1997, Final summary data assessment report for Operable Unit 1 Naval Undersea Warfare Center Division Keyport, Washington: Prepared by URS Consultants, Seattle, Washington, for Engineering Field Activity, Northwest, Naval Facilities Engineering Command, Poulsbo, Washington, 3 vols. 

Publishing support provided by the U.S. Geological Survey Science Publishing Network, Tacoma Publishing Service Center

For more information concerning the research in this report, contact the Director, Washington Water Science Center

U.S. Geological Survey

934 Broadway, Suite 300

Tacoma, Washington 98402

https://www.usgs.gov/centers/wa-water 
